\title{
Market Orientation Practices of Multinationals in Lagos, Nigeria
}

\author{
Adedoyin Rasaq Hassan ${ }^{1}$ \\ ${ }^{1}$ Marketing Unit, Department Business Administration and Management Technology, Faculty of Management \\ Sciences, Lagos State University, Lagos, Nigeria \\ Correspondence: Adedoyin Rasaq Hassan, Marketing Unit, Department Business Administration and \\ Management Technology, Faculty of Management Sciences, Lagos State University, Ojo, Lagos, Nigeria. E-mail: \\ doyinhassan200@yahoo.co.uk
}

\author{
Received: Novermber 25, 2011 Accepted: August 15, 2012 Online Published: September 10, 2012 \\ doi:10.5539/ijms.v4n5p139 URL: http://dx.doi.org/10.5539/ijms.v4n5p139
}

\begin{abstract}
This paper reports the survey of the Market orientation Practices of selected Multinational Corporations in Lagos, Nigeria using the opinions of four hundred and forty-two (442) purposively sampled respondents who were highly placed officers and managers in those corporations. This study investigates if Multinational organizations in Lagos attach a reasonable level of importance to the activities of their customers/clients and also examines the degree to which they ensure client/customer relationships within their organizations. The findings reveal that the companies investigated attach a reasonable level of importance to the activities of their customers and clients among many other market orientation practices which has led to improved success in their business operations. The study identifies some major problems faced by these multinationals and suggestions are proffered on how they could be ameliorated.
\end{abstract}

Keywords: market orientation, multinationals, customer/client relationships, customer orientation

\section{Introduction}

Nigeria, with an estimated population of 160million, is Africa's most populous nation. It offers investors abundant natural resources, a potentially large domestic market in Sub-Saharan Africa, and a low-cost labour pool. Unfortunately, much of that market potential is unrealized. Impediments to investment in Nigeria include inadequate infrastructure, corruption, inconsistent regulatory environment, misguided macroeconomic policies, inefficient system of registering property, slow and ineffective courts and dispute resolution mechanism.

Over the past ten years, Nigeria's skilled labour pool has declined as vocational and university educational standards have plummeted, mainly because of poor funding. Nearly half of all Nigerians are unemployed, and rely on the informal sector as a means of support because of the low employment capacity of Nigeria's formal sector. Again, most multinational businesses operating in Nigeria do not have confidence in the capabilities of Nigerians who they see as "relatively incompetent".

In the formal sector, companies involved in businesses such as banking and insurance possess an adequately skilled work force (some trained abroad, or home-based better funded universities), while in the manufacturing sector, workers often require additional training and supervision, but there are very few supervisory personnel to handle such.

Nigeria emerged a fair manufacturing nation in the areas of food processing, vehicles, textiles, pharmaceuticals, paper, cement, (etc.) as a result of the "oil money" earned by her, which gave her the enablement to import raw materials from other countries. Part of the effects of the oil boom was that there was a significant rural - urban migration caused in - part by the lure of high wages and consumer - oriented lifestyles of the city. This brought about the movement of a significant labour force away from the rural farms, leaving the very young, the old, and the infirm to cultivate the land.

With the wealth that she "should" have, Nigeria is still considered a third-world country nationwide, where the real standard of living has fallen sharply, and these are attributed to political instability, mismanagement and corruption, and the decline in oil prices. Virtually all the other sector companies are being dominated by the oil sector, and this has been of major concern to the environmental activists. 
The inflation rate in Nigeria has made the revenues of most companies seem as if they have not earned much, as the purchase value of the Naira $(\mathrm{N})$ has dropped tremendously. The present conversion rate of the Nigerian currency $(N)$ to the Dollar $(\$)$, Pound $(£)$ and the Euro $(€)$, has been a major source of worry to Nigerians, especially those who transact business internationally with superior nations as Europe, America, and other developed nations of the world. This pathetic situation has affected the operations of businesses in Nigeria. The progress of any business, results from the approach of the management in control of its activities.

In Nigeria, most businesses fail because of bad management practices; and it is on this note, that it has become a necessity to conduct an appraisal of the market orientation practices of multinational companies in Nigeria, who have hitherto controlled a reasonable part of the Nigerian market vis-à-vis customer/client orientation sensitivity competition, staff welfare, interdepartmental dispositions within the organization, profitability efforts, customer base management/growth, revenue target efforts, social responsibility, product/service quality, determination of short and long term goals, market share, personnel/staff satisfaction efforts of the company and others.

\section{Literature Review}

\subsection{The Multinational Company}

A multinational company (MNC) can be defined as a firm which conducts its activities, (excluding marketing) in more than one country, other than the one in which its head office is located (Asika, 2004). Put another way, a multinational enterprise is a company that is headquartered in one country, but has operations in other countries (Boddy, 2008; Oyedijo, 2002). These companies have a dramatic impact on the quality of goods and services that are being produced around the world, and they own or control production or service facilities outside the country in which they are based.

According to the United States Federal Trade Commission, (See Asika 2004), a firm can be accorded the status of a multinational if: it realizes a total turnover of at least $\$ 100$ million; owns subsidiaries in at least 6 countries, and has invested at least twenty percent (20\%) of its capital abroad. A Multinational Company is the split of company stock between shareholders from two or more different states. Multinationals distinguish themselves by relatively large sizes, and appropriate organizational structure assuring concerted action of all the parts of the system. They are located operationally in several overseas countries because they are most likely to be more profitable than single country and single plant operations. Firms become multinational in status basically because of the following 10 reasons among others (Oyedijo, 2002): to protect themselves from the risks and uncertainties of the domestic business cycle; to tap the growing world market for goods and services; response to increased foreign competition and protection of world market shares; to reduce operating costs from one stand point; to overcome tariff walls by serving a foreign market from within; to earn greater returns from their distinctive skills or core competencies and take advantage of technological expertise by manufacturing goods directly rather than allowing others to do it under a license; to increase sales and profits by becoming involved in less competitive situations; to increase a company's growth relative to its competitors by becoming involved in the international sphere; to realize location economics by dispersing particular value - creation activities to those locations where they can be performed most effectively, and to realize greater experience curve economies which reduce the costs of value creation.

MNCs vary in terms of size and mostly regarded as international companies with great importance to the economies of the nations where they operate. Business headlines focus sharply on large international companies because of their economic and political muscle that makes them highly visible, coupled with the fact that their dealings involve large sums of money (Wild.,Wild and Han,1999). Although it is becoming an encouraging trend to find small and medium-sized enterprises going international, but the large companies enjoy certain advantages, or some features that provide them the ability to perform more effectively in the global environment of business than other entrants (Inegbenebor and Agbadudu, 1995).

For such large corporations, the following characteristics enable them prosper where the smaller ones would fail: large human and materials resources, market mobility and search skills for favourable climates for their businesses; capital intensive operations and largeness in operational size. Multinational Corporations that possess the afore-listed features can be recognized by their country of origin; by the sectors they operate in; the volume of their assets, their sales and number of employees. Their largeness in this case is presented to mean a high degree of complexity in their activities, assets, labour force and market penetration capability. Multinationals also possess extensive Managerial capacity, huge investment in Research and Development (R and D), self-sustainability in imperfect markets, where the forces of Supply and Demand experience disequilibrium, where there is some possibility of governmental interference, where the conditions permit monopoly and where 
there are changes of repetitive advertising or collusion in pricing and vertical integration, where businesses are being combined at all levels.

Koontz, O' Donnell and Weihrich (1983) suggest that multinational corporations have several advantages over firms that have a domestic orientation, because the MNC can take advantage of business opportunities in many different countries, utilize capital markets throughout the world, recruit management and other personnel from a world-wide pool, establish production facilities in countries where their products can be produced most effectively and efficiently, and better access to raw materials and natural resources that may not be available to domestic firms. However, the major challenge usually faced by MNCs will be that of increasing nationalism in many countries.

\subsection{Multinational Companies and the Nigerian Economy}

The openness of an economy is a matter of degree as no economy is self-sufficient, but an economy may choose to fully close her boundaries. Generally, the lower the degree of self-sufficiency-either in the terms of productive capacity for local output, the higher the degree of openness.

In Nigeria situation, the high degree of openness is related more to the inadequacy of productive capacity for local demands. Technology, which is needed to transform the country's considerable natural resources into finished goods, is lacking. The country is now faced with the option of either exporting our raw materials for importation of technology with such other production factors as capital and managerial know-how, utilizing the local resources to produce goods for either local consumption or for export. The Nigerian crude oil is virtually refined abroad, and later imported back into the country in its desirable finished state.

Many companies in Nigeria, particularly the large ones, are subsidiaries of foreign multi-nationals (owned by foreigners) and most of those companies were fully owned by foreigners even up to the promulgation of the Nigerian Enterprises Promotion Decree (NEPD) of 1977. They drew their management staff from various nationalities, and own business and production outlets in several other countries. Nigerian Multinational Enterprises are mostly American and British in origin, and they are undoubtedly known for their advanced technology and management. Iyanda and Bello (1988) opine that the question of the reasons for the evolution and growth of MNCs in Nigeria can be answered from two (2) perspectives; one, the motivation of investing companies for going outside their national boundaries, and two, from the point of view of the national host countries (that is, the countries in which the MNCs or foreign enterprises are established).

Most businesses extend beyond their (geographical) territories because of excess domestic capacity, anticipation of higher profits in foreign countries particularly those with rapid rates of growth, and the need for earnings stability provided by diversified geographical operations. Again, the situations in the host countries may be so 'welcoming' for foreign investors because of certain granted concessions by government in their policies such as lower taxation, insurance against expropriation and so on.

The attractiveness of MNCs to a developing country like Nigeria is borne out of the country's needs and characteristics. Nigeria is generally short of capital, limited technology, unimpressive managerial skills and manpower, unemployment, poor standard of living and an increasingly huge population among other problems.

The earliest modern Nigerian businesses having been established and managed by foreigners are 'multinational' and such largely commercial businesses applied little or no technology nor transferred much capital or managerial skills to Nigeria.

In Nigeria, familiar multinational corporations are mainly Americans, European/Far East based (Inegbenebor and Agbadu, 1995); they include the following:

ii. American: Coca-Cola, IBM, Pfizer, Texaco, Chevron, (formerly Gulf), Uniroyal, Gillette, Dow Chemical, GEC, General Motors, Exxon, Addax (formerly Ashland oil) etc.

ii. European/Far East: Britain: Shell-BP, Beecham, Unilever, Switzerland: Nestle, Hoffiman, La Roche, Japan: Hitachi, France: Michelin, CFAO, SCOA, Total, Elf, etc, Germany: Feber Werke, etc.

Multinational companies in Nigeria have been described as catalysts of global industrialization, carriers of technology and partners in progress towards growth and development (Asika, 2004).

Major justifications for the encouragement of multinational enterprises in Nigeria can be explained as follows:

- Multinationals contribute to the economic growth and development of a country by creating demand for productive factors of the country and transforming materials into useful (utility generating) forms. 
- Multinational companies create more profits, management, and marketing techniques that enhance the general quality of life within a country. Local companies in Nigeria fashion their operations after that of the multinationals operating within the country, who they see as 'superior'.

- They serve as a vital channel through which Nigeria can effectively obtain access to those intangible resources such as technological knowledge and management expertise.

- Investment activities of multinational companies have become the main dynamic element behind the tremendous expansion in national trade in the past decade in Nigeria.

- Multinational activities guarantee a nation of long term economic survival and profit maximization through the exploitation of local raw materials, training of local labour, export development, etc. Again, Multinationals contribute significantly to the economic development of Nigeria through additions to domestic value added or factor incomes, expending foreign exchange earning capacities through export development and productivity spillovers.

Besides helping Nigeria to increase domestic factor incomes, foreign investment provides the country access to the export markets. Aside the listed justifications for MNCs, Inegenebor and Agbadudu (1995) suggest other justifications to include: innovation, research and development; social responsibility; introduction of new products and re-development of old one; reduction in gap of differentness among cultures and increased rate of cross cultural assimilation and transformation; professional expertise; manpower development and managerial and environmental rationale (among others).

\subsection{Strategic Orientations of International Firms}

Multinational Companies have strategic pre-dispositions towards doing things in a particular way. Oyedijo (2002) identifies four main pre-dispositions: Ethnocentric Predisposition, which refers to a multinational company's values and interests, that are peculiar to the parent company itself towards the formulation and implementation of its strategy for doing business abroad (Koontz, O'Donnell and Weihrich, 1993); Polycentric Predisposition, where a multinational corporation will tailor its strategy to meet the needs of the local culture where it operates. If the firm is doing business in more than one culture, the overall plan will be adapted to reflect these individual needs; Regeocentric Predisposition, where a multinational firm will be interested in obtaining both profit and public acceptance (a combination of the ethnocentric and polycentric approaches) and will use a strategy that allows it to address both local and regional; and, Geocentric Predisposition, Which allows a multinational company to view operations on a global basis. This approach is widely in use by most large international corporations.

\subsection{Customer Orientation}

Many companies are beginning to realize that they often pay more attention to their sales/revenue targets rather than being customer-driven. The company management should become more market focused and customer-centered too. The CEO must personally exemplify strong customer commitment and reward those in the organization who do likewise (Kotler 1997; Osuagwu, 2002 and Obaji, 2009). His justification for customer orientation arises from the failed product situation of same companies where customers were not allowed input into the product formulation initially.

Too many companies still design their products without customer input, only to find them rejected in the market place. Also, too many companies forget their customers after sale, only to lose them to competitors later. Several motivational publications on customer orientation such as; "Turning lost customers into Gold", "Customer binding", "The customer-driven company" etc., stress one theme; future successes rest on a market and customer-based view of business success. Such companies focus on customer developments in designing its marketing strategies and on delivering superior value to those customers (Kotler and Armstrong, 2010). Brandt (2007) suggests that outstanding marketing companies go out of their way to keep important customers satisfied. Most studies show that higher levels of customer satisfaction lead to greater loyalty, which in turn results in better company performance. Delighted customers make repeat purchases, become willing marketing partners and "customer evangelists" who spread the word about their good experiences to others. Studies on customer-driven businesses reveal that customers often return for more transactions after the first experience often tagged as "memorable" (Barker, 2008; Gallo, 2008 \& 2007; Liu, 2007 and Torres, 2006). 


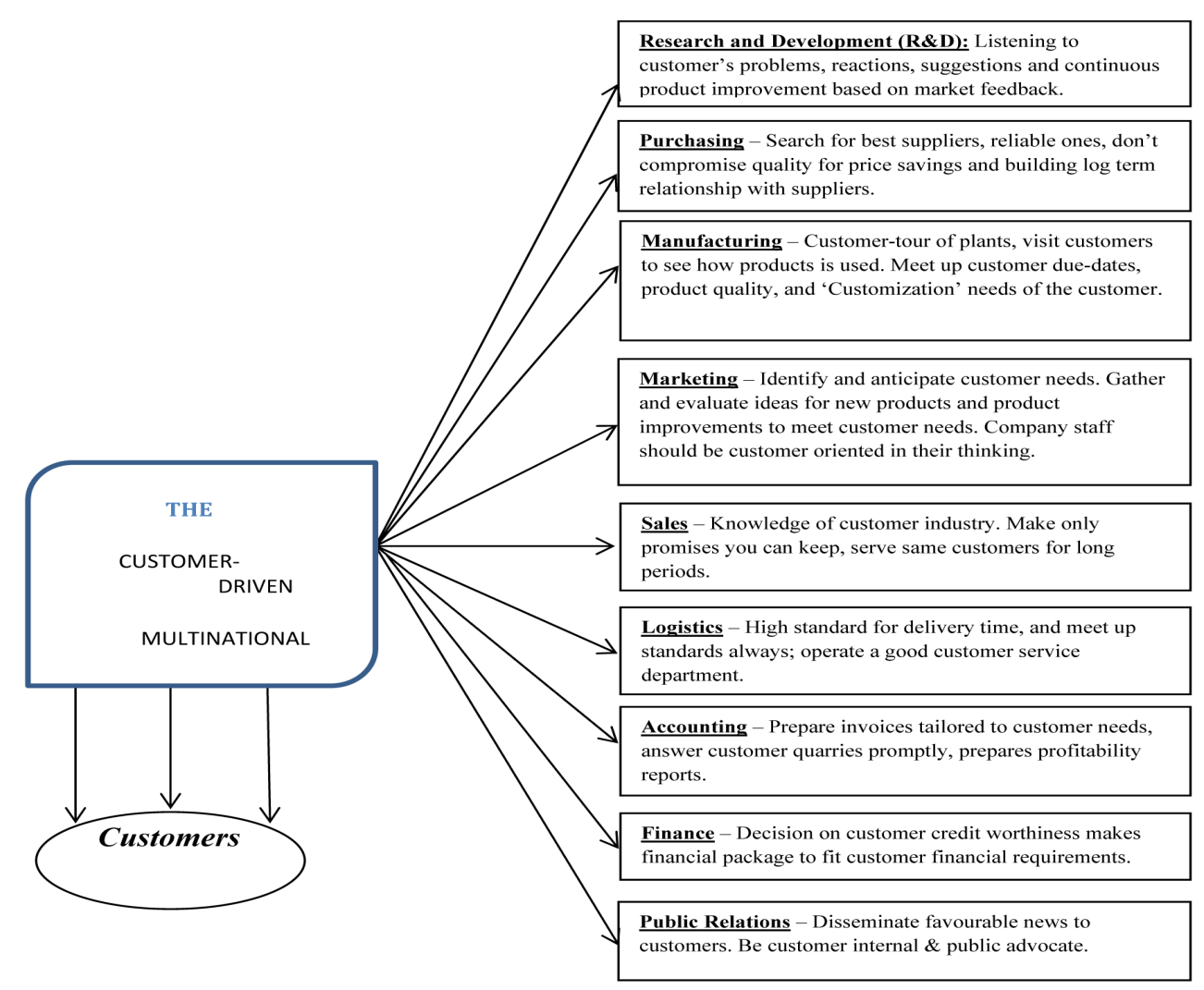

Figure 1. The customer-driven multinational company

Source: Developed by writer based on the works of Kotler, P. (1997) Marketing Management, implementation and Control ( $9^{\text {th }}$ ed.). Prentice-Hall Inc. p762.

Osuagwu (2002) dwells on the fact that Client/Customer orientation requires a clear understanding of the Client/Customer (that is, the Client/Customer needs, wants, and behaviour) as basis for marketing decision. Etzel, Walker and Stanton (1997) subscribe to the customer orientation view, saying that every department and employee should be focused on contributing to the satisfaction of customer's needs. Customer-oriented and co-ordinated market is essential to achieve the organisation's performance objectives. Again, Osuagwu (2002) suggest that any organization unable to provide goods and services that fulfill the needs and wants of consumers has lost its basic reason for existence. This is the crux of marketing concept, which encouraged organization to be customer-oriented in order to survive in a competitive environment. Figure 1 is a model on the activities of customer-driven companies where all the business efforts of the company is geared towards customer satisfaction in the areas of needs vide Research and Development (R\&D), Purchasing, Manufacturing, Marketing, Sales, Logistics, Accounting, Finance and Public Relations. The yardsticks featured in figure 1 model can also be adapted by competitors centered companies if they must meet up.

\section{Objectives of the Study}

The basic objective of this study is to ascertain if the selected multinational companies in Lagos-Nigeria attach a reasonable level of importance to the activities of their customers/clients and to examine the degree to which they ensure client/customer relationships with their organizations. The problems being faced by these multi-national companies in the course of their basic operations shall also be identified.

\section{Research Methods}

The basic study area of this research work is Lagos, which is believed to be the commercial nerve-centre of most foreign multinationals and most business activities in Nigeria, coupled with its cosmopolitan nature and the highest degree of population density it has amidst all the states of the Nigerian federation. The research interaction was restricted to sophisticated and intellectually high company executives who had thorough knowledge of the companies in which they operate. 
The sampling technique adopted for this study is a blend of purposive and Judgmental sampling. Purposive in the sense that only executives working in multi-national companies operating in Nigeria were chosen as respondents because it is believed that it is only their opinions that can answer the questions of this research. The sampling method is partly judgmental because the researcher had to make a first-hand assessment of the potential respondents to ascertain if he or she fits the description of "intellectually sophisticated marketing executive" criterion prescribed for this research study. The interviewed executives were drawn from the textiles, fast foods, manufacturing, banking, extractive, telecommunications, building construction and building industries in Nigeria that have

The researcher could not completely gather a substantial part of the questionnaire data until over seven (7) weeks after the questionnaires were given out to respondents. Although some executives were magnanimous enough to fill their questionnaires instantly (roughly half of the respondents), but some others held on to the questionnaires for longer period on the excuse of having tight schedules on their jobs that did not give them much time to face the filling of the questionnaire. Out of the 500 questionnaires administered, 442 of them were returned. A master data sheet was developed by the researcher, after which an SPSS computation was conducted to derive the frequency tables, descriptive statistics, factor analysis, and correlation Matrix, among others. The data gathered were analysed with use of simple percentages to reveal respondents' polls on the various degrees of response which spanned through "No extent at all", "very low extent", "low extent", "arrange extent", high extent", and "very high extent", where 1, 2, 3, 4, 5 and 6 values were attached to the various degrees respectively (as shown in the frequency distribution table..

\section{Significance of the Study}

This research work is expected to give a first time foreign investor who wants to gain an insight into business activities in Nigeria a clear picture of things in the business regard.

Again, it is expected to meet up with providing information to research endeavours by academics and other individuals in the area of business practice. The recommendations of this study will, to a great extent, address the problems being faced by multinational business organizations in Nigeria, and such problems include that of funding, inadequate infrastructure, bad roads, insufficient raw materials, customer satisfaction, political instability among others. This study is expected to be a pointer to other areas of study within the same topical concept that will attract a worthwhile research effort of other scholars in the same or related disciplines. Generally, the various discoveries about multinational companies in Nigeria in the areas of customer/client orientation, competition, sub-unit inter-relationship within the organization, revenue/profit realization and staff matters among others is expected to be of immense contribution to the body of knowledge in the area of Marketing, Business Administration, and other related disciplines.

\section{Discussion of Findings}

\subsection{Bio-data of Respondents}

All the 442 respondents (280 males and 162 females) under survey resided in Lagos and their organizations were also situated in Lagos, as at the period of study. They ranged between the ranks of officer and manager. $84 \%$ of the respondents indicated that a range of at least 10-100 employees served actively within their organization while the remaining $16 \%$ had over 100 employees, with just $1 \%$ of them spanning beyond 500 employees. $84.2 \%$ of them had a minimum of first degrees in forms of Bachelors and Higher diploma degrees in management and other allied disciplines. 56.8\% of the respondents had professional papers in forms of ACCA/ICAN/ATS from the accounting sphere of business practice and the certificate of the Chartered Institute of bankers of Nigeria (CIBN) while only $6 \%$ of them had masters and PhD degrees. $30 \%$ of the respondents did not indicate any claim in the area of professional qualifications. $65 \%$ of the 442 respondents had at least $1-5$ years of work experience in their various organizations, while $23.3 \%$ of them had worked for over 5 years and above while $10 \%$ of them had worked for over 15 years.

Table 1. Respondents' frequency according to industry type

\begin{tabular}{lll}
\hline Industry & Frequency & Percentage \% \\
\hline 1. Services & 103 & 23.3 \\
2. Manufacturing & 225 & 50.9 \\
3. Others & 114 & 25.8 \\
Total & $\mathbf{4 4 2}$ & $\mathbf{1 0 0}$ \\
\hline
\end{tabular}

Source: 2010 field survey 
A major number of the respondents $225(50.9 \%)$ worked in manufacturing organisations, while $103(23.3 \%)$ were service company workers. $114(25.8 \%)$ of the respondents belonged to other organizations as building construction, fast foods and printing, etc.

\subsection{Respondents' Reactions to Research Statements}

The degrees of response ranged between NEAA $=$ No Extent At All (1), VLE=Very Low Extent (2), LE=Low Extent (3), $\mathrm{AE}=$ Average Extent (4), HE=High Extent (5) and VHE=Very High Extent (6).

Table 2. Respondents' reactions on the market orientation practices in their organizations

\begin{tabular}{|c|c|c|c|c|c|c|}
\hline \multirow{2}{*}{ Research Statements } & \multicolumn{6}{|c|}{ Frequencies } \\
\hline & NEAA & VLE & LE & $\mathrm{AE}$ & HE & VHE \\
\hline $\begin{array}{l}\text { Commitment to serve the needs and wants of its } \\
\text { customers / clients }\end{array}$ & 0 & 0 & 12 & 25 & 65 & 340 \\
\hline $\begin{array}{l}\text { Frequent and systematic customers' / clients' } \\
\text { satisfaction. }\end{array}$ & 0 & 0 & 3 & 10 & 67 & 362 \\
\hline $\begin{array}{l}\text { Company's knowledge of clients / customers in its } \\
\text { sector of business activity. }\end{array}$ & 1 & 2 & 11 & 20 & 100 & 308 \\
\hline $\begin{array}{l}\text { Maintaining regular contacts with present and } \\
\text { potential customers by company executives }\end{array}$ & 0 & 1 & 5 & 15 & 123 & 298 \\
\hline $\begin{array}{l}\text { Accommodation of customers' / clients ideas and } \\
\text { suggestions in order to improve on the company's } \\
\text { business activities. }\end{array}$ & 0 & 2 & 8 & 42 & 113 & 277 \\
\hline $\begin{array}{l}\text { Company's frequent study of customer / clients to } \\
\text { know the future value attached by customers / } \\
\text { clients to company's business activities }\end{array}$ & 1 & 1 & 7 & 65 & 99 & 279 \\
\hline $\begin{array}{l}\text { Company's ability to rapidly detect changes in the } \\
\text { preferences of its customers / clients }\end{array}$ & 1 & 1 & 30 & 75 & 110 & 255 \\
\hline $\begin{array}{l}\text { Company's encouragement of customers / clients to } \\
\text { make comments and complaints about its business } \\
\text { activities }\end{array}$ & 0 & 1 & 1 & 3 & 40 & 397 \\
\hline $\begin{array}{l}\text { Company's frequent examination of probable effect } \\
\text { of environmental changes on its customers / clients }\end{array}$ & 1 & 1 & 5 & 40 & 101 & 295 \\
\hline $\begin{array}{l}\text { Company's awareness of any form of important } \\
\text { happenstance to its customers / clients within a } \\
\text { short period of time }\end{array}$ & 0 & 2 & 16 & 30 & 92 & 306 \\
\hline $\begin{array}{l}\text { Companies define the quality of their business } \\
\text { activities in terms of customers' / clients' } \\
\text { satisfaction. }\end{array}$ & 1 & 1 & 6 & 20 & 102 & 312 \\
\hline $\begin{array}{l}\text { Companies focus on what is of value to its clients / } \\
\text { customers in the course of planning and } \\
\text { development of new business activities }\end{array}$ & 0 & 1 & 5 & 43 & 99 & 294 \\
\hline $\begin{array}{l}\text { Companies' efforts at keeping promises made to } \\
\text { customers / clients }\end{array}$ & 0 & 0 & 2 & 16 & 111 & 313 \\
\hline $\begin{array}{l}\text { Customers' / clients' complaints are attended to } \\
\text { rapidly in their companies }\end{array}$ & 1 & 1 & 3 & 45 & 117 & 275 \\
\hline $\begin{array}{l}\text { Companies have achieved growth in customer base } \\
\text { through their business operations. }\end{array}$ & 0 & 2 & 21 & 54 & 65 & 300 \\
\hline $\begin{array}{l}\text { Companies have achieved improved customers' / } \\
\text { clients' satisfaction level through their business } \\
\text { operations. }\end{array}$ & 0 & 0 & 9 & 40 & 100 & 293 \\
\hline
\end{tabular}

Source: 2010 field survey

Table 2 is a composite frequency distribution table of the 442 respondents in respect of the core research statements made by researcher survey questionnaire. 
At least $70 \%$ of the respondents expressed very commendable efforts on the part of their organizations in the areas of: commitment to the service of customer/clients' needs and wants; frequent and systematic customers'/clients satisfaction; accurate knowledge of customer/clients' activities; encouragement of customer/clients' in making comment and complaints about their business activities; and keeping promises made to customers/clients. A remarkable success was made by $68.9 \%$ of the organizations in the achievement of growth in customer base through their business operations. Furthermore, $71 \%$ of the organizations surveyed were comfortably able to define the quality of their business activities in terms of customer/clients' satisfaction while maintaining regular contacts with their potential and present customers. A combination of the High Extents (HE) and the Very High Extents (VHE) responses in table 2 reveals that a highly significant majority of the multinational companies in Nigeria claimed that to be actively involved in customer orientation practices which has led to successful business performance in the area of profitability.

Table 3. Problems facing multinationals in Nigeria (by ranking)

\begin{tabular}{|c|c|c|c|}
\hline & Problems & Frequency & Percentage \\
\hline a. & $\begin{array}{l}\text { Funding, inadequate infrastructure and political } \\
\text { instability. }\end{array}$ & 141 & $31.8 \%$ \\
\hline b. & Economic problem, inflation \& political instability & 111 & $25 \%$ \\
\hline c. & $\begin{array}{l}\text { Bad roads, insufficient raw materials and poor } \\
\text { managerial skill }\end{array}$ & 91 & $20.5 \%$ \\
\hline d. & Transportation problem and poor supply & 49 & $11.4 \%$ \\
\hline e. & $\begin{array}{l}\text { Lack of marketing and customer orientation, } \\
\text { non-access to loan }\end{array}$ & 20 & $4.5 \%$ \\
\hline \multirow[t]{4}{*}{ f. } & $\begin{array}{l}\text { How to satisfy customers and maintaining high level } \\
\text { of return }\end{array}$ & 10 & $2.3 \%$ \\
\hline & Total & 435 & $98.4 \%$ \\
\hline & Missing (blank) & 7 & $1.6 \%$ \\
\hline & total & 442 & $100 \%$ \\
\hline
\end{tabular}

Source: 2010 field survey

Table 3 shows that 141 (31.8\%) of the 442 respondents that opined that their companies are faced with 3-major problems of funding, inadequate infrastructure and political instability are on top of the list ; followed by a quarter of them, (111) that stated economic problems, inflation and political instability being the 3-major problems facing their companies. The third most important group of problems facing the respondents is the problems of bad roads, insufficient raw materials and poor managerial skills. Next, are the problems of transportation and raw material supply, followed by lack of marketing/customer orientation and non-accessibility to loan facility, while the least of the respondents' problems were how to satisfy customers and maintaining a high level of return.

\subsection{Validity and Reliability of Research Instrument}

Table 4. Factor analysis (KMO and Bartlett's test) for validity (442 cases)

\begin{tabular}{rll}
\hline Kaiser-Meyer-Olkin measure of sampling Adequacy & 0.765 \\
\hline Bartlett's Test of Sphericity & Approx Chi-square & 142.658 \\
& df & 45 \\
& Sig & .000 \\
\hline
\end{tabular}

Source: Statistical Package for the Social Sciences (SPSS) Survey Print-out

The KMO value for the test of whether factor analysis can be carried out on this study is 0.765 , which is greater than the 0.70 minimum value postulated by Nunally (1979). The implication of this is that factor analysis can be carried out on this study and that the instrument used has a reasonable degree of content validity. 
Table 5. Reliability analysis on 442 cases

\begin{tabular}{ll}
\hline Reliability Coefficients & \& Value (Alpha) \\
\hline Alpha \& & 0.9252 \\
Standardized item \& & 0.9390 \\
\hline
\end{tabular}

Source: Statistical Package for the Social Sciences (SPSS) Survey Print-out

The Cron-bach alpha value for test of reliability on the above study is 0.9252 , and the standardized item alpha is 0.9390. The figures show a very high degree of reliability when accessed in line with Cron-Bach (1947)'s recommendation of 0.70 minimum value reliability. The implication of this is that the instrument used in the research is capable of yielding the same result if re-applied in a similar environment to the place of study (Cron-Bach, 1947 and Churchill, 1995).

\section{Conclusions and Recommendations}

Based on the fore-going findings, the following conclusions can be deduced about multinational business operating in Lagos, the commercial nerve centre of Nigeria: First, companies under study attach a reasonable level of importance to the activities of their customers and clients; Second, multinational companies operating in Lagos have their business practices based on the variables in existence within their sectors of operations especially when they plan, monitor and detect basic changes in the environment; third, Nigerian multinational organisations attach a high degree of importance to inter-departmental relationships within their operations, through periodic meetings, report dissemination on future issues in the relevant business environment, and tackling of detected important changes in other competing companies; fourth, multinational businesses operating in Lagos have been impressive in the areas of profitability, customer based growth, sales turnover, revenue, reduced cost, market share, personnel / staff satisfaction, social responsibility, product/service quality, unit sales, short and long term goal achievements, and general overall performance. The findings align with the works of Obaji (2009) and Olumoko (2011) on their recent survey of the market orientation Practices of Multinationals and Small Business Enterprises in Nigeria respectively.

The recommendations proferred below are drawn basically to tackle the problems of multinational companies (MNCs) (both service and product) that were under survey in the course of this study.

1) Multinational Business Organisations should include in their line-up of programmes, social responsibilities as assisting Government in the area of infrastructural provisions such as road and water, which will not only be appreciated by the environs but will facilitate movement around the business areas and also the distribution / logistic problems will be eased.

2) Corporate organisations should digress a little into the areas of public enlightenment, especially in the area of politics in order to minimize, if not totally erase the problem of political instability in Nigeria.

3) Banks and other financial outlets can be co-opted into partnership in lucrative ventures such as agriculture, animal husbandry, fisheries etc, which no doubt will yield profits not only to the companies and the banks / financial institutions, but will create employment opportunities for Nigerians who have hitherto been redundants / unemployed. Companies will no longer lament on the problem of accessibility to Loan facility from Banks.

4) Multinational companies should sponsor their employees, to attend short and / or long courses on management, so that they can improve on their managerial skills, not only for the administrative benefits the organisation, but towards the realization of short and long term goals of business.

5) Local sourcing raw materials will reduce the cost of production and will in turn cut-down product prices within the economy. By so doing Inflation problems can be eased.

6) More organisations should draw attention to the area o scholarship so that managerial and productive talents can be developed to transform the operations of the business.

7) Multinational organisations should create move outlets in other areas other than the Headquarter offices in order to enhance proximity to potential and actual co-ordinate the activities of these outlets through networking (information technology).

8) A sound integrated marketing programme should be put in place to create awareness for products/services offered by the companies. Sponsored consumer anticipation identification studies should be organized so that the feelings, needs, and wants of the consumers can be discovered. This will help the business in the areas of product 
and service planning. By so doing, the company is sure that the products/services are being fashioned in line with the yearnings and aspirations of the actual and potential buyers.

It is expected that sub-sequent studies on the Business Management Practices of Nigerian Companies may focus on: Market orientation practices of multinational organisations in other states of Nigeria, so that a comparative study can be made with Lagos; and a study of the environmental factors affecting the operation of Multinational Businesses in Nigeria.

\section{References}

Ajonbadi, H. A. (2000). Applied Business Management Theory. Lagos: Vantage Publishing, 8.

Asika, N. (2004). Introduction to International Business. Lagos: Rothmed International.

Barker, J. (2008). Power to the People. Incentive, Feb, 34.

Bartlett, C., \& Ghosal, P. (1995). Transnational Management: Text, Cases and readings in Cross-Broader Management (2nd ed.). Boston: Irwin McGraw-Hill.

Boddy, D. (2008). Management: An Introduction (4th ed.). England: Pearson Education Limited, 118.

Brandt, D. R. (2007). For Good Measure. Marketing Management, Jan/Feb, 21-25.

Churchill, G. A. (1995). Marketing Research: Methodological foundation (5th ed.). London: Dryden Press.

Cronbach, L. T. (1947). Test Reliability: Its Meaning and Determination. Psychometrical, 12(1), 1-16. http://dx.doi.org/10.1007/BF02289289

Crowther, J. (1995). Oxford Advanced Learner's Dictionary Oxford. Oxford University Press.

Czinkota, R. M., \& Ronkaimen, A. I. (1992). Global Marketing 2000; A marketing survival Guide. Journal of Marketing Management, Winter, 37-45, 748.

Doole, I., \& Lowe, R. (2000). International Marketing Strategy; Analysis, Development and Implementation (2nd ed.). London: Thomson Learning, 11, 33, 458.

Etzel, J. M., Walker J. B., \& Stanton, J. W. (1997). Marketing (11th ed.). U. S. A: McGraw-Hill Companies Inc, $538,545$.

Gallo, C. (2007). The world's Best Hotels where luxury lives. Institutional Investor, November, 1.

Gallo, C. (2008). Employee Motivation the Ritz-carlton Way. Businessweek, Feb. 29. Retrieved from http://www.businessweek.com

Hodgetts, M. R., \& Luthans, F. (1997). International Management (3rd ed.). Singapore: McGraw-Hill Companies Inc.

Inegbenebor, A. U., \& Agbadudu, A. B. (1995). Introduction to Business: A functional Approach (1st ed.). Benin-Nigeria. Uri Publishing Limited, 223-225.

Iyanda, O., \& Bello, J. A. (1988). Elements of Business in Nigeria (1st ed.). Lagos: University of Lagos Press, 261-279.

Keegan. J. W. (1989). Global Marketing Management (4th ed.). Englewood cliffs, New Jersey: Prentice Hall Inc, 7-10.

Koontz, H., O’Donnel, C., \& Weihrich, H. (1983). Management. Japan: McGraw-Hill Inc, 135-139.

Kotler, P. (1997). Marketing Management; analysis, planning, implementation and control (9th ed.). U. S. A: Prentice Hall Inc. 227-244, 425, 762.

Kotler, P. (2003). Marketing Management (11th ed). U. S. A: Prentice Hall Inc. 384.

Kotler, P., \& Armstrong, G. (2010). Principles of Marketing (13th ed.). New Jersey: Pearson education Inc. glossary, G.3.

Lancaster, G., \& Massingham, L. (2001). Marketing Management. Britain: McGraw-Hill Publishing Company.

Liu, Y. (2007). The Long-Term Impact of Loyalty Programs on Customer Purchase Behaviour and Loyalty. Journal of Marketing, October, 19. http://dx.doi.org/10.1509/jmkg.71.4.19

Miihlbacher, H., Dahringer, L., \& Leihs, H. (1999). International Marketing; A Global Perspective (2nd ed.). London: International Thomson Business Press, 56, 748. 
Nwokoye, G. N. (2000). Modern Marketing for Nigeria: Principles and Practice. Nigeria: Rex Charles and Patricks Limited.

Obaji, R. N. (2009). Factor Analytic Approach to market Orientation Practices in multinational companies. An Unpublished PhD Thesis submitted to the Department of Business administration, Lagos state university, Ojo.

Odugbesan, O., \& Osuagwu, L. (1999). Marketing Promotions and Sales Management. Lagos: Pumark Nigeria Limited, 11.

Olumoko, T. A. (2011). Market Orientation Practices of Small Business Organisations in Lagos. A Postfield doctoral seminar paper submitted to the Nassarawa State University, Nigeria.

Osuagwu, L. (2002). Marketing, Principles and Management (2nd ed.). Lagos: Grey Resources Limited, 255, $292,719$.

Osuagwu, L. C., \& Gbadamosi, G. (1998). Fundamentals of Marketing. Lagos: Malthouse Press Limited, 9, 12.

Oyedijo. (2002). International Business; Key concepts in Business. Lagos: Strategic International Press Limited.

Porter, E. M. (1980). Competitive Strategy. USA: The Free Press, a division of Macmillan Publishing Co. Inc. 293.

Torres, B. (2006). Jeans Genes Part of Price Tag Formula. Knight Ridder Tribune Business News, Nov.

Wild, J. J., Wild, K. L., \& Han, J. C. (1999). International Business; An integrated approach (e-business updated ed.). U.S.A: Prentice Hall Inc., 14, 21, 27.

Wilson, R. M., \& Gilligan, C. (1999). Strategic Marketing Management: Planning, Implementation and Control (2nd ed.). Great Britain: The Bath Press, Bath, 123. 